\title{
TRAÇOS DO COTIDIANO, ESSA VIDA DE "POUCO CASO"
}

\author{
Mitsi Pinheiro de Lacerda ${ }^{1}$
}

\begin{abstract}
Resumo: O artigo, de natureza ensaística, objetiva agregar à defesa da relevância dos estudos em cotidianos, uma modesta contribuição. A princípio, é estabelecido diálogo entre teóricos que se dedicaram aos estudos da vida cotidiana, e a literatura - compreendida enquanto possibilidade de conexão entre a vida comum e a ciência. Na segunda seção é estabelecida conversação com algumas tentativas de "menorização" da vida cotidiana, o que tem sido feito, continuamente, por meio da alegação de que esta esfera seria, tão somente, a repetição diária de si, alimentada por conhecimentos que não são oriundos do campo científico. A seguir, é inserida uma narrativa de forma a vitalizar esta conversação, buscando na memória, um pouco da escola. Por fim, a conclusão do ensaio conduz o leitor a aproximar-se deste estranho, o pesquisador em cotidianos.

Palavras-chave: Vida Cotidiana; Literatura; Escola; Ciência e Senso Comum.
\end{abstract}

\section{A CONVERSATION ABOUT EVERYDAY LIFE}

Abstract: The article intends to aggregate a modest contribution to the defense of the relevance of everyday life studies. At first, a dialogue is established between theorists who have dedicated themselves to the study of everyday life and literature - understood as the possibility of connection between ordinary life and science. The second section comprehends a talk about some attempts to "undervalue" everyday life, which has been done continuously through the allegation that this sphere would be just the daily repetition of itself, nourished by knowledge that is not derived from the scientific field. Next, a narrative is inserted in order to fortify this conversation, searching the school in memory. Finally, the conclusion leads the reader to approach this stranger, the researcher in everyday life.

Keywords: Everyday Life; Literature; School; Science and Common Sense.

${ }^{1}$ Doutora em Educação, Professora do Departamento de Ciências Humanas e do Programa de Pós-Graduação em Ensino da Universidade Federal Fluminense.

Momento: diálogos em educação, E-ISSN 2316-3100, v. 26, n. 1, p. 118-142, jan./jun. 2017 


\section{VIDA COTIDIANA, LITERATURA E HISTÓRIA}

Em suma, sem romance, não há historicidade. ${ }^{2}$

Michel de Certeau

Ao observar a operatividade da racionalidade científica, gerada há quinhentos anos, Boaventura Santos (2002) ressalta que sua hegemonia é firmada via desqualificação do senso comum e dos estudos humanísticos - aí inclusa a literatura. Acuada, a literatura defendeu-se buscando refúgio no estruturalismo, de forma a escapar da alegação de não ser científica. Para Boaventura Santos (2002), a cisão entre ciência e literatura será dissipada a partir da literatura, quando esta, corajosamente, der início às negociações e diálogo com a ciência, através de uma "transgressão metodológica" (p. 49). Ele defende a "literaturização" da ciência, estabelecendo conexões com a expressão artística e assumindo uma escrita que acolha a forma e o conteúdo dos conhecimentos produzidos à margem. Se é na vida cotidiana que se passam e se proliferam histórias (cujo enredo e sentido são conferidos por aqueles que as vivenciam), e se é objetivo da ciência desvelar a vida - que a ciência seja, portanto, literaturizada.

Anterior ou concomitante às análises e conceitualizações teóricas, a História tem sido, em grande parte, registrada no âmbito da literatura. Divorciados da ciência, no século XVII, os textos literários clandestinamente mantêm sua postura de vanguarda, anunciando, astuciosamente, indícios daquilo que pulsa na sociedade (CERTEAU, 2011). Uma breve incursão através da escrita literária, revela registros históricos imersos em contextos críticos, seja explícita, ou tacitamente. Dialogando com o que se passa na sociedade, a literatura tem entrelaçado, em sua expressão artística, traços provenientes de diversas áreas do conhecimento, bem como as contradições postas pela realidade social.

Em $O$ Cortiço, publicado em 1890, adentramos, com Aluísio Azevedo (2001), na vida cotidiana dos moradores de um cortiço, os quais são, em grande parte, trabalhadores de uma pedreira e consumidores dos produtos disponíveis em uma venda. Todos estes lugares - o cortiço, a pedreira e a venda, são de propriedade do português João Romão, amigado com a negra Bertoleza e, posteriormente, noivo de Zulmira. A leitura da obra produz, no leitor, a percepção de proximidade a estes ambientes, adentrando intimamente nas diferentes lógicas postas pelos sujeitos. João Romão, inicialmente um pobre coitado, cresce econômica e socialmente no decorrer da história, e sua ascensão é alimentada, exclusivamente, pela

\footnotetext{
${ }^{2}$ Cf. Michel de Certeau (2011, p. 96).

Momento: diálogos em educação, E-ISSN 2316-3100, v. 26, n. 1, p. 118-142, jan./jun. 2017
} 
exploração do outro. Seu crescimento, porém, converte em obstáculo a presença da companheira que sempre estivera a seu lado: Bertoleza.

E não podia deixar de pensar no demônio da negra, porque a maldita ali estava perto [...]; ali estava como o documento vivo das suas misérias, já passadas. Mas, ainda palpitantes. Bertoleza devia ser esmagada, devia ser suprimida, porque era tudo que havia de mau na vida dele! Seria um crime conservá-la a seu lado! Ela era o torpe balcão da primitiva bodega; [...] era o sono roncado num colchão fétido, cheio de bichos; ela era a sua cúmplice e era todo seu mal - devia, pois, extinguir-se! Devia ceder o lugar à pálida mocinha de mãos delicadas e cabelos perfumados, que era o bem, porque era o que ria e alegrava, porque era a vida nova, o romance solfejado ao piano, as flores nas jarras, as sedas e as rendas, o chá servido em porcelanas caras; era enfim a doce existência dos ricos, dos felizes e dos fortes, dos que herdaram sem trabalho ou dos que, a puro esforço, conseguiram acumular dinheiro, rompendo e subindo por entre o rebanho dos escrupulosos ou dos fracos (AZEVEDO, 2001, p. 108) (sic!).

Azevedo (2001) denuncia, em sua literatura, as misérias infligidas aos negros, pois sabia que nem a "abolição" que estava em curso, seria capaz de reverter o desespero de uma vida subtraída. Quem mais claramente percebe isso, é Bertoleza. Silenciosamente, ela observa as mudanças que ocorrem em João Romão e em seu entorno, notando, também, sua mais recente aspiração: descartá-la. Este dia não tarda a chegar: João Romão a denuncia à polícia, como escrava fugida. A polícia chega e, acuada nos fundos da cozinha, Bertoleza atinge fatalmente seu próprio ventre com uma peixeira, enquanto, à porta principal da casa, uma comitiva de abolicionistas chega em busca de João Romão, para outorgar-lhe diploma pela benemerência. Diante de Bertoleza, morta, ele é avisado sobre a chegada dos visitantes e ordena que sejam conduzidos à sala de visitas, de forma a que possa receber sua "justa" homenagem.

Azevedo (2001) desenha, em detalhes, a cotidianidade de quem desgraçadamente vive no cortiço, sinalizando a continuidade do escorraçamento de Bertoleza e as doloridíssimas misérias humanas, decorrentes de uma existência orientada pelas desigualdades sociais. Sua obra trata da conversão de um vendeiro em explorador, exibindo o avanço do capitalismo e sua materialização nas vidas de pessoas comuns. Consideradas as diferentes temporalidades desde as quais o texto teórico e a literatura alcançam o público, é possível inferir que, antes mesmo de acessar a teoria econômica, parte da população brasileira teve acesso ao conhecimento das perversidades capitalistas, via literatura.

Mediado por seu inconformismo e insubmissão ao cânone da disciplina, quem também se interessava por buscar interlocução na literatura, era Michel de Certeau. Padre jesuíta nascido em uma pequena cidade francesa, em 1925, chama a atenção, em sua biografia, o fato dele ter se constituído pesquisador fora da universidade - o que contribuiu para que sua Momento: diálogos em educação, E-ISSN 2316-3100, v. 26, n. 1, p. 118-142, jan./jun. 2017 
formação não sofresse influência do modelo de cientificidade hegemônico. Sua relação com o conhecimento era liberta das fragmentações postas ao saber, o que tece a bela herança com a qual nos presenteia. Segundo Luce Giard, sua colaboradora:

Pelo leque de seus interesses de estudo, pelo entrecruzamento dos métodos que pratica sem prestar vassalagem a nenhum deles, e pela diversidade de suas competências, Certeau intriga e desconcerta. No tabuleiro de uma profissão de gostos geralmente sedentários ele não para de se movimentar e nunca se identifica com um lugar determinado (CERTEAU, 1994, p.10).

Certeau (1994) anuncia que as práticas cotidianas costumam ser caracterizadas, desde um olhar externo, como orientadas pela passividade dos que se encontram sob dominação. Senhor de um campo que toma como base, o "forte" impõe a normatividade regulatória a partir da qual o "fraco" deve circular, consumir, reproduzir. Para isso, o "forte" estabelece e administra estratégias, estabelecendo, segundo Certeau, a postulação de um "próprio"3, uma prática panóptica e um poder que determine um saber (p. 99).

Em meio a este campo regulado pelo "forte", o "fraco" se movimenta. Em resposta a cada registro regulatório, este cria alternativas e subverte o que está posto, cautelosa e silenciosamente. Quase não é visto, já que no âmbito da regulação não estão previstas as iniciativas do "fraco". Suas práticas não são capitalizadas, posto que são sempre inéditas, comprometidas com o sentido que as forja e com o momento que as possibilita. Melhor dito por Certeau:

A uma produção racionalizada, expansionista além de centralizada, barulhenta e
espetacular, corresponde outra produção, qualificada de "consumo": esta é
astuciosa, é dispersa, mas ao mesmo tempo ela se insinua ubiquamente, silenciosa e
quase invisível, pois não se faz notar com produtos próprios mas nas maneiras de
empregar os produtos impostos por uma ordem econômica dominante (CERTEAU,
1994, p. 39).

Ao afirmar a existência, na sociedade, dos dispositivos disciplinares analisados por Foucault (1987), Certeau provoca deslocamentos ao pensamento. Mostrando sua coexistência com a inconformidade, destaca, nos praticantes submetidos ao controle e vigilância, a resistência ao que lhes é imposto. Sem desprezar a existência de uma força hegemônica, a curiosidade certeuniana persegue o desmonte cotidiano, microscópico e multiforme desta força. Como resistência às "estratégias" previstas pelo "forte" - aquele que configura e domina um campo -, o "fraco" tece "táticas" que "vão desembocar então em uma politização das práticas cotidianas" (p. 45). O ato político cotidiano, portanto, não guarda qualquer

3 Segundo Certeau, "O "próprio" é uma vitória do lugar sobre o tempo. Permite capitalizar vantagens conquistadas, preparar expansões futuras e obter assim para si uma independência em relação à variabilidade das circunstâncias. É o domínio do tempo pela fundação de um lugar autônomo" (CERTEAU, 1994, p. 99).

Momento: diálogos em educação, E-ISSN 2316-3100, v. 26, n. 1, p. 118-142, jan./jun. 2017 
relação com uma ação planejada, centralizada e verticalizada: ele acontece quando se configura uma ocasião. Contrário às lógicas que presidem as ações ordenadas, o ato político cotidiano é um acontecimento, pois que se faz em seu acontecer. Impulsionado pela “consciência crítica de suas relações sociais imediatas" (MARTINS, 2014, p. 105) e pelos conhecimentos que produz de forma compartilhada, o "fraco" faz uso das ocasiões que se configuram para si e, sorrateiramente, conduz a própria vida.

Alimentado por seu precioso olhar positivista, um observador externo dificilmente consegue ver as miríades de ações políticas que ocorrem continuamente nos cotidianos. Seu olhar sobrepõe o protótipo do que seria um ato político, sobre o que encontra no cotidiano - e o que consegue ver, é tão somente seu modelo empobrecido. Certeau adverte quanto a isso, tratando da impropriedade de se utilizar uma lógica hegemônica, na aproximação das trajetórias indeterminadas dos praticantes do cotidiano - sujeitos que fazem uso da ocasião para realizar o que habita seus desejos (1994, p. 46). Ele ensina que a aproximação, mediada por uma lógica tecnocrática, não é capaz de compreender os movimentos empreendidos pelos praticantes do cotidiano, nem tampouco de notar suas aspirações. Ignorante acerca dos quereres e artimanhas do "fraco", o "forte" o desqualifica, assim como desqualifica também o campo que habita: a vida cotidiana. A menorização dos sujeitos comuns, do senso comum e do cotidiano é legitimada desde o pronunciamento de um "discurso competente" (CHAUÍ, 1997), o qual, "mediante curiosa operação, [...] converte a competência em autoridade" (CERTEAU, 1994, p. 66 - destaque do autor).

Esta autoridade forjada contribui para que o "forte" circunscreva um campo que sirva de base às suas operações de dominação. $\mathrm{O}$ "forte" delimita um lugar desde o qual inscreve sua racionalidade e normatizações, objetivando o controle do "fraco". Seu aparente êxito é expresso na posse do lugar. Desprovido de um "próprio", resta ao "fraco" a percepção apurada do decorrer do tempo, durante o qual se mantém vigilante, de forma a aproveitar a ocasião (Idem, Ibidem, p. 46). As estratégias do "forte" produzem, mapeiam e impõem operações que o "fraco", com suas táticas, utiliza, manipula e altera.

Qualquer garoto entende bem sobre isso. Em sua trajetória escolar, sua sala de aula pode ser apropriada por uma lógica que não é a sua, e à qual é orientado a sucumbir. Este lugar - a sala de aula - pode ter muitos elementos configurados de forma a lhe dizer, continuamente, qual é o padrão. Sua carteira é posicionada atrás da carteira de alguém com quem gostaria de puxar um assunto; a professora passa boa parte da aula cumprindo 
demandas que não são suas; os textos que circulam na classe não são escolhidos ou escritos por este garoto; as tarefas a serem cumpridas são postas pelo autor do livro didático; o toque de uma sirene determina quando ele poderá ir para casa; ele não pode dizer o que aprendeu, mas é obrigado a registrar, na prova, o que lhe foi ensinado (VALLA, 1996); o garoto precisa pedir autorização para fazer xixi, subordinando sua fisiologia a um imperativo externo. Em meio a tudo isso, rapidamente o garoto entende que se encontra em um lugar que não é seu, e rapidamente também entende que o tempo é seu aliado na morosa invenção de táticas que subvertam tudo isso. O tempo passa, o garoto observa, pensa e, quando se configura uma ocasião ótima, ele age. Talvez, tenha conseguido travar o tal assunto com o colega da frente, ou, quem sabe, a professora tenha ido à secretaria, e ele tenha escapulido para o banheiro. Mas pode ser que ele não tenha conseguido nada, nadinha. Pode ter passado quatro horas aguardando sua ocasião, mas para mal dos pecados, tudo "mascou". Isso, contudo, não entristece esse menino sabido; amanhã, ele aguardará novamente, folha levada pelo vento que é. O que se passou hoje, passou; mas o que planejou hoje, não poderá ser mantido para amanhã. Como aprendemos em Certeau, uma tática não se capitaliza (Idem, Ibidem, p. 48).

Caminhante do cotidiano e interessado nas práticas comuns, Certeau recorria a personagens literários, de forma a estabelecer conexões entre o pensamento teórico, e os sujeitos ordinários (CERTEAU, 1994, p. 31). Os personagens literários faziam funcionar outros caminhos perceptivos para o leitor, o que tornava a escrita conceitual acessível. Para tratar da vida cotidiana, Certeau traz consigo Robinson Crusoé (DEFOE, 1719, Reino Unido), o qual, após naufrágio no mar, permanece durante vinte e oito anos isolado em uma ilha deserta. Ali, ele inventa outro modo de vida, e isso é observado com curiosidade por Certeau. Como em um certo dia, em que Crusoé se dá conta de que precisa registrar a passagem do tempo, e decide criar um calendário. Nascido no berço da civilização ocidental, ele dispunha de um modelo: horas, dias, semanas, meses, anos. Porém, este modelo não se ajustava ao que vivia naquele lugar, então Crusoé cria um calendário que marcaria a temporalidade, segundo a percepção que passara a ter da natureza. Estabeleceu, portanto, que seu calendário registraria o tempo molhado e o tempo seco. Isso seria suficiente para que organizasse a vida cotidiana, o plantar, o colher, o pescar, o armazenar.

Os modos como Crusoé inventava o cotidiano interessavam a Certeau, assim como algo parecido, também adentrava o trabalho de Henri Lefebvre, em seu encontro com o Ulysses, de James Joyce (2012). O livro, em suas 1.106 páginas, atravessa um dia da vida de 
Leopold Bloom, um homem comum - o que levou Lefebvre a mergulhar naquele 16 de junho (LEFEBVRE, 1991). Seguindo a direção de Lefebvre, sem decalcar o seu traçado, fui também à busca deste livro instigante, amado e odiado em seus extremos por diferentes pessoas; um livro bastante analisado, discutido, dissecado e explicado - enquanto sua essência, o mantém como segredo.

Na primeira página do Ulysses, encontramos a famosa piada, na qual se indagaria a Joyce, o que ele andara fazendo durante a Grande Guerra, e sua suposta resposta: "Eu escrevi o Ulysses. E você?”. Num esforço infinitamente menor, e que se resumiu a ler um livro que pesa um quilo e duzentos gramas, gosto de brincar também, dizendo que, durante as férias, “eu li o Ulysses (e você?)”. Antes de ler o Ulysses, nas preliminares de uma leitura indiciária, entendi que, assim como o cotidiano, não seria possível tecer sentidos sobre este livro lendo apenas uma parte. Bem no início eu já me sentia "fora", embora insistisse em percorrer a escrita de forma a encontrar, quem sabe, uma porta de entrada.

A chave desta porta de acesso à leitura deveria ser produzida, mas enquanto sua matéria prima era proveniente de quem estava do lado de fora, sua forma só poderia ser conferida por quem estava dentro. Momentos de paralisia e movimento; por vezes me sentia perdida, por vezes me sentia fluir junto ao texto. A leitura deste livro causa certa estranheza, pois, junto ao esforço por criar outra história ao ler, o leitor precisa também prestar atenção e perseguir o pensamento do autor, caso contrário, não compreende. Isso difere de uma leitura na qual é preciso "matar o autor" (BARTHES, 2004), para se apropriar e transmutar o texto segundo os sentidos que se desenham na leitura. Armadilha de Joyce: mate-o, e fique à deriva.

Esse sentimento me fez pensar sobre a vida cotidiana: ela está ali, é a vida de todos nós, todos os dias. Podemos nos aproximar, viver, criar e observar esta vida, mas nem sempre conseguimos acessar os sentidos, quando se trata de cotidianos alheios. Embora os lugares de sua ocorrência (o trabalho, a casa, a praça e outros) sejam semelhantes, as lógicas de consumo e a inventividade tendem ao singular.

Em sua narrativa, Joyce mescla o que o Sr. Bloom vê, o que diz, o que faz, sente e o que pensa, e seu registro salta da $3^{\mathrm{a}}$ para a $1^{\mathrm{a}}$ pessoa do singular, continuamente. Quem narra a história? Quem é o observador? Perseguir a simultaneidade entre a caminhada, narrativa e pensamento do Sr. Bloom não é uma tarefa linear, já que, às vezes, este sujeito observado desaparece do relato, e a cena é focalizada a partir de outro ponto. A narrativa adentra o pensamento do Sr. Bloom, mostrando seu pulular caótico: às vezes direcionado, outras vezes, Momento: diálogos em educação, E-ISSN 2316-3100, v. 26, n. 1, p. 118-142, jan./jun. 2017 
não. O livro se faz naquilo que Bakhtin (1992) ensina: que o pensamento não tem a mesma estrutura sintática da fala. O pensamento é desconexo (aparentemente), porque o pensador não precisa explicar, a si mesmo, o que pensa. Lendo os pensamentos de Bloom, às vezes me perdia, porque seus pensamentos, aerados, não encontravam similitudes nos meus.

Enquanto trabalha, come, caminha e pratica várias atividades cotidianas, o pensamento de Bloom atravessa sua linguagem e suas práticas, caoticamente. Percebendo a aparente desconexão entre o que pensa, diz e faz, ele sinaliza que, rizomaticamente, "uma coisa leva à outra" (p. 307). E assim é o pesquisador em cotidiano ${ }^{4}$ : sua busca se alimenta de encontros inusitados e dificilmente prescritos, e seus achados perdem o sentido quando submetidos a uma ordenação linear. Isto porque "uma coisa leva à outra", sem que a coisa desde a qual se parte, disponha de qualquer conexão aparente com a outra coisa à qual se chega. A história convida a uma episteme, assumindo que "o pensamento é o pensamento do pensamento" (p. 126).

Assim como em uma passagem do livro, por exemplo, em que o Sr. Bloom encontra um homem cego na calçada, e se propõe a ajudá-lo a atravessar a rua. Neste encontro, ele observa o cego e, a princípio, o subestima: "coitadinho desse moço! Como foi que ele soube que aquela carroça estava lá? [...] Deve ter uma ideia bem estranha de Dublin, abrindo caminho a bengalada pelas pedras." A princípio, Bloom pretensamente tenta ver a cidade pelo cego, mas, por fim, admite sua ignorância, pensando que "é a gente que fica surpreso que eles não sejam estúpidos" (JOYCE, 2012, p. 332). Se aprendermos com Bárcena (2015) que o termo "idiota" implica em "seres carentes de una existencia política" (p. 49), e, ainda, recorrermos à tão conhecida afirmação de Certeau, de que "não devemos tomar os outros por idiotas", quem sabe podemos compreender a dimensão política da vida cotidiana, e, com o admirado Bloom, indagar porque nos causa espanto descobrir que o outro, assim como nós, também pensa.

Tudo isso é maravilhoso, mas o que me encanta neste livro é a ideia da enormidade de um dia, a imensidão de um segundo. O que me instiga é encontrar complexos se desenhando em um instante, e passagens supostamente insignificantes, se agigantando em turbilhões de sentidos. Em meio a eventos cotidianos microscópios, desdobram-se possibilidades

\footnotetext{
${ }^{4} \mathrm{O}$ uso da preposição $\underline{\mathrm{em}}$ sinaliza conexões entre os termos de uma oração, potencializando sentidos entre eles. Em se tratando de cotidianos, a preposição no converte o cotidiano em lugar e estabelece limites entre este suposto lugar, e o observador. Cotidianos não são lugares, por isso a opção por pesquisar em cotidianos. Momento: diálogos em educação, E-ISSN 2316-3100, v. 26, n. 1, p. 118-142, jan./jun. 2017
} 
insuspeitáveis para o conhecimento de si - o que revela que a vida cotidiana não abriga uma história rasa, mas se tece em uma miríade de bifurcações férteis.

E o que seria a vida cotidiana? De forma a estabelecer conversação com esta pergunta, vou ao encontro de diversos autores, para com eles, aprender. Em Agnes Heller (1970) sabemos que esta é a vida de todos nós, o que temos em comum; uma vida que é a mesma para todos, embora hierarquizada pelas condições materiais de existência, e pelo espaço e tempo em que se passa. Tanto o "nobre", quanto o "pobre", transcorrem por suas vidas cotidianas, grandemente diferenciadas em seus aspectos materiais, e distintas segundo as imposições do quadro econômico, social e político. Ambos dispõem de cotidianidade ${ }^{5}$ : caminham, conversam, trabalham, cozinham, consomem - mas a hierarquização das possibilidades acessíveis a cada um, transforma a vida cotidiana em depositária das desigualdades sociais.

A vida cotidiana é cadenciada pela rotina e pela repetição, o que a cristalizaria enquanto o mesmo. Porém, no interior daquilo que seria inerte, Gabriel Tarde (2003) e Gilles Deleuze (1988) perceberam diferenciações sutis que imprimem movimento à vida, alterando, microscópica e silenciosamente, sua aparência e essência. No século XIX, no auge da supremacia positivista que organizava as ciências humanas emergentes, Tarde (2003) trabalhava com uma "microssociologia", buscando nos detalhes da trama social, seu fluxo e sentido. Ele afirmava que "existir é diferir", e que em tudo o que se repete, algo novo é propagado. A repetição seria, então, o transporte para o novo - sua condição de possibilidade. Para ele, a diferença se mostra sutilmente entre duas repetições, o que convida a observar os interstícios, e a descartar o que é possível objetivar. Gabriel Tarde (2003) percebia a pulsação humana e social, bem como a natureza vertical e cristalizada das ações instituídas:

Se olharmos o mundo social, o único que nos é conhecido por dentro, vemos os agentes, os homens, bem mais diferenciados, mais caracterizados individualmente, mais ricos em variações contínuas, do que o mecanismo governamental, os sistemas de leis ou de crenças, os próprios dicionários e as gramáticas, mantidos pela participação dos agentes. Um fato histórico é mais simples, mais claro do que qualquer estado de espírito de um de seus atores (TARDE, 2003, p. 66).

Pois é no interior dos conflitos entre estes diferentes estados de espírito, e, sobretudo, na consciência crítica acerca da realidade, que brota grande parte da História. Quem ensina isso é Agnes Heller (1970), para quem a História principia na vida cotidiana, onde esta mesma História se deposita. Envolto em finíssimo papel de seda azul, talvez repouse, em algum lugar

\footnotetext{
5 A noção de "cotidianidade" foi criada por Henri Lefebvre.

Momento: diálogos em educação, E-ISSN 2316-3100, v. 26, n. 1, p. 118-142, jan./jun. 2017
} 
do mundo, um brinquedo; preservado, apesar da grande bomba, este suposto brinquedo poderia falar da cotidianidade, mesmo que sua criança tenha sido impedida de continuar a sorrir. O fato Histórico - a bomba - é redutível a si; a verdadeira História, aquela que pulsa, arde e se desdobra, esta acontece, realmente, nas infinitesimais reminiscências que se perpetuam nas vidas das pessoas.

Fértil celeiro da produção de sentidos e da "experiência" (LARROSA, 2014), a vida cotidiana é o espaço e tempo em que se atravessam os processos micro e macro estruturais, no interior dos quais, cada um vivencia densamente o que é de si, enquanto afeta o outro, continuamente. Mostrando-se como "rizoma" (GALLO, 2013), cotidianos são irredutíveis a categorias, ordenações, linearidades e causalidades; não se confundindo com o "lugar", um cotidiano se desdobra em deslocamentos, segundo sua própria intencionalidade.

Até aqui, ofereci a "entonação" que julguei necessária a esta escrita, de natureza ensaística, e cuja intenção é agregar à defesa da relevância dos estudos em cotidianos, uma modesta contribuição. O artigo está dividido em três partes, sendo que, na primeira, estabeleço conversação com algumas tentativas de "menorização" da vida cotidiana, o que tem sido feito, continuamente, por meio da alegação de que esta esfera seria, tão somente, a repetição diária de si, alimentada por conhecimentos que não são oriundos do campo científico. A seguir, insiro um breve relato, de forma a vitalizar esta conversação, buscando na memória, um pouco da escola. Por fim, concluo o ensaio aproximando-me deste estranho, o pesquisador em cotidianos.

\title{
A PRODUÇÃO DA INEXISTÊNCIA DO COTIDIANO
}

\author{
Nada é mais perturbador \\ que os movimentos incessantes \\ do que parece imóvel. ${ }^{6}$ \\ G. Deleuze
}

Certeau (1994) e Lefebvre (1991) afirmam que, antes da modernidade, não havia vida cotidiana - esta vida civilizada e ocidental, que fragmenta espaçostempos e os especifica enquanto trabalho, lazer, vida privada, consumo. Anteriormente à modernidade, as necessidades provenientes da vida eram supridas pelas próprias mãos que as consumiam, segundo os sentidos que atribuíam àquilo que criavam. Com a revolução industrial, este modo de vida se dissipou, surgindo a figura do consumidor e a possibilidade de exploração e alienação. Certeau (1994) defende que, apesar desta realidade - e também devido a ela - no

\footnotetext{
${ }^{6}$ Cf. Gilles Deleuze (1992, p. 200).

Momento: diálogos em educação, E-ISSN 2316-3100, v. 26, n. 1, p. 118-142, jan./jun. 2017
} 
cotidiano é que se processa a inventividade dos praticantes. Vítimas de incessantes tentativas de sequestro, os praticantes, inconformados, se asseguram de si, reinventando a vida, e escapando à ordenação hegemônica. Os que desqualificam a vida cotidiana, acusando a existência de uma suposta infertilidade, circunscrita por margens estreitas, não conseguem ver a dimensão política e a lucidez que residem na criatividade e fuga dos praticantes.

Caso esta infertilidade, que lhe tem sido atribuída, fosse verídica, a vida cotidiana poderia passar desapercebida, reduzida ao tamanho que lhe fora imputado: o tamanho menor. Caso a vida cotidiana se resignasse a ser este suposto espaçotempo de repetições infinitas de eventos insignificantes, não haveria necessidade da manutenção, em curso permanente, de um projeto que visa a sua menorização (LACERDA, 2015b).

Sendo a vida cotidiana a vida de todos nós, este espaçotempo deveria ser a condição de possibilidade ao compartilhamento de uma vida bonita para toda a humanidade. Todos nos alimentamos, repousamos, realizamos atos de higiene, trabalhamos - e nisso somos todos (quase) iguais. E somos "quase", porque embora as ações cotidianas sejam as mesmas para todos, entre elas há distinções postas pela intensidade de injustiça social presente em cada lugar. As distinções surgem qualitativa e quantitativamente, quando, por exemplo, um prato de comida é abastecido com os nutrientes necessários à vida humana, enquanto outros pratos permanecem vazios. Para camuflar a diferença posta ao que deveria ser igual, o pensamento hegemônico se esforça por menorizar a esfera cotidiana, já que uma breve observação dos cotidianos, permitiria revelar as desigualdades sociais que assolam o mundo. Esta lógica perversa sabe que não são apenas nos índices da economia que se revelam as injustiças sociais, mas nas insuficiências impostas à cotidianidade da maior parte da população mundial.

A menorização do cotidiano faz parte de um projeto maior de dominação, e suas ações se veiculam a aspectos da vida cotidiana, de forma a subtrair, deles, sua força de expansão. Um desses aspectos afetados, é a repetição - a vida cotidiana que se repete, todos os dias. Tornando a repetição sinônimo de esterilidade, e associando-a à inexistência de novidade, a modernidade exclui aqueles (as) que não consomem o "novo" (mesmo que seja para descartalo em seguida). "Como atribuir importância ao que acontece diariamente, da mesma forma, por todo lugar?" - indaga o "forte", ao desdenhar do que quer comprar?.

\footnotetext{
${ }^{7}$ O ditado popular, "quem desdenha, quer comprar", faz alusão ao ato de não se atribuir importância ao que se deseja, de forma a subtrair do objeto desejado, o seu valor. 
A repetição é o "motor da vida" a gerar transformações em meio à continuidade, sem que nos desintegremos - e isso é o suficiente para que seja inclusa em um projeto de menorização. Sem a vida cotidiana que se repete todos os dias, não seriam possíveis as sutis conquistas sociais, e as invenções cotidianas de táticas de sobrevivência. Como aprendido em Certeau (1994, p. 102), o "fraco" necessita do tempo para realizar suas aspirações, uma vez que o espaço é dominado pelo "forte". Por isso a repetição, tão necessária à vida, é desqualificada enquanto rotina, mesmice e inércia - e por ser a repetição uma característica da vida cotidiana, sua desqualificação também a afeta. E se é assim com a repetição, também o é com o senso comum - alimento e vestígio de toda a vida cotidiana. Entendido que a tessitura do senso comum tem por berço a cotidianidade, e que é em seu interior que são gerados, dialeticamente, os sentidos privilegiados pelas pessoas, há de se reconhecer que o senso comum é impregnado por culturas, e que se somos seres de culturas, dá-se a entender que o senso comum é parte indissolúvel de nós. Daí a desqualificação, também, do senso comum, de forma a incluir, na versão dominante desta história de "pouco caso ${ }^{8}$,, os cotidianos e também a nós, gentes comuns, que é o que somos todos.

Curioso notar que, um projeto hegemônico, interessado tão somente por ver à distância, tenha percebido os movimentos microscópicos produzidos pela repetição na vida cotidiana, além de ter notado a proliferação do senso comum. Para melhor compreender isso, é preciso entender, primeiramente, sobre a interferência das escalas que empregamos ao observar a realidade. Boaventura Santos (2006) ensina que os fenômenos, pelos quais nos interessamos, são dimensionados pelas escalas que privilegiamos - a grande ou a pequena escala. Através de uma "cartografia simbólica", a grande escala se aproxima dos fenômenos observados, ao aumentar o zoom da observação; já a pequena escala amplia o campo de observação, perdendo, com isso, a percepção dos detalhes ${ }^{9}$. Para Boaventura, estes modos antagônicos de percepção sobre a realidade implicam, de forma complementar, em uma apreensão qualitativa do mundo. A pequena escala seria, então, responsável por identificar posições, uma vez que seu olhar abrangente capta o quantitativo e a distribuição espacial de elementos, examinando-os e mensurando-os, nas relações que estabelecem entre si; quanto à grande escala, dada a sua proximidade em relação a uma realidade ampliada, se interessaria por movimentos e detalhes:

\footnotetext{
8 O dicionário registra que "pouco caso" significa falta de apreço, de consideração; desprezo, indiferença, desdém.

${ }^{9}$ Para facilitar o entendimento, eu diria que a observação de sua rua é realizada em grande escala, e a de sua cidade, em pequena escala. 


\begin{abstract}
A legalidade de grande escala é rica em detalhes, descreve pormenorizada e vivamente os comportamentos e as atitudes, contextualiza-os no meio envolvente e é sensível às distinções (e relações complexas) entre familiar e estranho, superior e inferior, justo e injusto. [...] Ao contrário, a legalidade de pequena escala é pobre em detalhes e reduz os comportamentos e as atitudes a tipos gerais e abstractos de aç̧ão. Mas, por outro lado, determina com rigor a relatividade das posições (os ângulos entre as pessoas e entre as pessoas e as coisas), fornece direcções e atalhos, e é sensível às distinções (e às complexas relações) entre parte e todo, passado e presente, funcional e disfuncional. Em suma, esta forma de legalidade cria um padrão de regulação baseado na orientação e adequado a identificar movimentos (SANTOS, 2002, p. 152)
\end{abstract}

O que se repete, na vida cotidiana, imprime diferenciações mínimas aos eventos, dificultando a que sejam detectadas por uma observação em pequena escala. As diferenciações mínimas, provocadas pelas repetições cotidianas, escapam à apreensão da cientificidade canônica - bem como escorrem por entre as frestas da regulação, impressas pelo poder. Em momentos assim, um suposto senhor de "querer e poder", indagaria: "Como investigar ou dominar um espaçotempo que se movimenta sorrateiramente? Como coletar e analisar dados provenientes desta esfera escorregadia, pela qual circula uma linguagem metafórica, e que é orientada por conhecimentos que não dispõem de base científica? Como dialogar com a vida cotidiana, espaçotempo no interior do qual o senso comum renitentemente se prolifera? Como capturar algo que não se revela em sua exibição?" Ah, o poder e suas inquietações...

Estabelecendo como base um "próprio", o "forte" normatiza seu campo científico, empresarial, industrial, escolar, urbano, político, linguístico e outros. A partir desta base, estabelece seu sistema teórico, burocrata, tecnicista, regulatório, limítrofe, demagógico, cultural. Sua episteme ignora a legitimidade da vida cotidiana, e sua racionalidade produz "formas sociais de não-existência [...]: o ignorante, o residual, o inferior, o local e o improdutivo" (SANTOS, 2006, p. 104). Todas estas formas sociais são depositadas na vida cotidiana, e se prestam a qualificar os sujeitos, alimentando projetos de dominação. Sabemos bem o que significa produzir algo, ou seja, propiciar a existência de algo: misturo alguns ingredientes, asso no forno, produzo um bolo. Mas, e sobre a produção da inexistência de algo? Como tomar o bolo e fazer acreditar que ele não existe? A desqualificação, e a menorização, constituem o método deste projeto direcionado ao silenciamento da potência cotidiana que, apesar disso, se expande continuamente.

O cotidiano é o humilde e o sólido, aquilo que vai por si mesmo [...] sem que o interessado tenha de examinar as articulações dessas partes. [...] É o insignificante (aparentemente); ele ocupa e preocupa e, no entanto, não tem necessidade de ser dito, é uma ética subjacente ao emprego do tempo, uma estética da decoração desse tempo empregado (LEFEBVRE, 1991, p. 31). 
O cotidiano não é um lugar, que fique claro isso. O cotidiano de uma praça, não é a praça; o seu cotidiano doméstico, não é a sua casa. O cotidiano, em Certeau (1994), é um "espaço praticado", ou seja, um lugar que foi transfigurado através da atividade incessante de praticantes, que o fizeram espaço. Penso em cotidianos, enquanto espaços que se fazem e se desfazem, sem se materializarem, ou se dissolverem; sendo feitos, não existem enquanto lugar circunscrito; e sendo desfeitos, continuam a existir, como potência política da expressão dos sujeitos. Os infinitos espaços praticados que configuram os diferentes cotidianos, se atravessam continuamente, livres dos lugares que os denominam.

Enquanto escrevo este artigo, sentada à mesa de minha casa, vivencio o cotidiano desta existência: sinto o cheiro do café, vindo da cozinha; ouço a movimentação da rua, e imagino o que se passa por lá; vejo um livro esquecido no sofá, e sei que uma amiga virá buscá-lo; Totoy, meu cão, passa correndo pela sala, e sei que alguém está chegando. Junto a isso, latentes em mim, outros cotidianos, tão meus: a escola, a praça, o trabalho e tantos outros. Enquanto habito a casa, sou afetada por cotidianidades diversas, que não se deixam determinar pelo lugar.

Em Certeau (1994), indeterminadas são as práticas cotidianas que não podem ser codificadas, assim como são indeterminados os seus percursos, que não podem ser prescritos. Indeterminadas são as lógicas desde as quais as práticas cotidianas ocorrem, pois, enquanto o sistema "produz o lugar", e também a "necessidade pelo lugar", os praticantes dele se apropriam, segundo os sentidos que privilegiam. Lugares são palimpsestos, mas a racionalidade hegemônica só reconhece aqueles que ela produz, ou sua superfície observável. Certeau (1994) diz que não há justaposições no lugar, mas sim estratos, camadas. Para o "forte", no lugar há elementos fixados, que compõem um cenário marcado por seu caráter regulatório. Para cada coisa, um lugar, uma serventia e um projeto de homogeneização. Tal justaposição de elementos, pode ser encontrada na cidade: no centro, a praça, e no entorno o judiciário, o executivo, o legislativo, “a” religião; também, na escola: no centro, o pátio, e no entorno, as salas de aula, a diretoria, a supervisão; assim como, na casa burguesa: no centro, a sala de estar, e no entorno, o dormir, o comer, o assear-se. A cidade, a escola e a casa especificam, a partir da distribuição de seus elementos constituintes, os modos fixados para o consumo do lugar.

E, assim como as práticas, as trajetórias e as lógicas que as alimentam, indeterminado também é o tempo e seu mais íntimo amigo: o imprevisto. Impossível de ser pensado pelos 
arquitetos dos tempos, o imprevisto também tem sido expulso do pensamento científico. Há o tempo para aprender a ler e, findo o prazo destinado a este fim, o aprendiz é destinado a uma nova categoria, a do fracassado, incapaz. Há o tempo para aprender a falar e, findo o prazo destinado a este fim, o falante é encaminhado ao especialista. Especialistas são sujeitos que atuam sobre os efeitos produzidos pelo fracasso da regulação. Não são os praticantes que fracassam, mas sim, a regulação. É ela quem determina o que, como e onde tudo deve se passar, e, dada a singularidade desmedida de cada um de nós, seu projeto jamais abarcará a todos (as). A grande maioria dos fracassos, produzidos pela regulação, e todos os projetos de menorização, revelam os indetermináveis, aqueles que consomem o lugar, tornando-o um espaço praticado; aqueles que fluem em sua própria temporalidade, que inventam a vida cotidianamente, que não se deixam aprisionar no interior de uma racionalidade única.

\section{RELATO: A LINGUAGEM COTIDIANA}

Daquilo que cada um faz o que é que se escreve? ${ }^{10}$ Michel de Certeau

Era um programa de TV que exibia um homem que falava sobre a cidade em que morava, e que para isso contava casos sobre o "que já aconteceu aqui", sobre "o que significa aquilo ali”. Eu assistia, interessada, quando meu filho chegou, quis saber o que era, eu expliquei e também comentei que "o programa era transmitido em inglês, mas era fácil entender tudo". Ele permaneceu ali, assistiu comigo ao programa e quando terminou, foi cuidar da vida; mas não sem antes dizer, assim como quem diz algo desimportante, que “qualquer pessoa entende esse inglês, ele está contando histórias".

É bom botar reparo nas coisas. Marcelo notou algo que não me ocorrera, que a língua estrangeira não se mostrava plena de sentidos, dado o domínio que tínhamos de seus aspectos sintáticos ou léxicos, mas porque o moço na TV contava histórias. O compartilhamento de seu relato nos acolhia em seu interior e se sobrepunha a quaisquer dificuldades linguísticas e ao accent.

Pois se história é algo que todo mundo entende, vou contar uma. Por muitos anos professora de escolas, pude vivenciar cotidianos escolares que, em muito, contribuíram para a constituição da minha experiência docente. Trago, então, uma história de escola ${ }^{11}$, de forma a

\footnotetext{
${ }^{10}$ Cf. Michel de Certeau, 1994, p. 106.

${ }^{11} \mathrm{O}$ registro foi realizado em uma escola pública estadual, no município de Carangola, interior de Minas Gerais, onde a autora trabalhava como professora do Ensino Fundamental. A inserção desta história, neste ensaio, intenciona ressaltar a relevância das infinitas histórias não documentadas que tecem os cotidianos das escolas. Momento: diálogos em educação, E-ISSN 2316-3100, v. 26, n. 1, p. 118-142, jan./jun. 2017
} 
estabelecer conversação com o inaugural que reside na vida cotidiana. Antes disso, uma vez que me proponho a tecer um relato, é importante lembrar que, para Certeau (1994), há modos de proceder da memória, que não cumprem a expectativa pelo arquivo e desvelamento do que se passa, mas que atuam na inventividade de outra coisa. A memória não é a reprodução, mas a alteração de algo, pois "essas escrituras invisíveis só são claramente lembradas por novas circunstâncias" (p. 163). A singularidade da memória reside em detalhes, que são trazidos de diferentes ocasiões, e bricolados na invenção daquilo que se quer pensar; sua mobilidade imprime fluidez à caça destes detalhes, sendo que, quem tece sua trama, é quem se põe a lembrar. Narrar a partir da memória, seria dizer, novamente, o que se passou, negando o que se passou, e criando outra história. A memória não é o relato linear de uma lembrança. Ela é tecida no encontro e em interlocução com aquilo que ela não é. Quando saboreamos um alimento, por exemplo, isso aciona memórias que não são a reprodução de um momento vivido, mas que produzem outras vivências. Toda memória, é uma outra história.

Meu interesse por escolas acompanha o que se passa a partir do uso dos praticantes (CERTEAU, 1994), em meio a relações não muito propensas ao exibicionismo. Preciso me aproximar para conhecer as miudezas, os movimentos microscópicos, as sutilezas, a privacidade que reside na intimidade. Os detalhes, persigo-os.

Para isso, me arrisco enquanto "tradutora". Para Boaventura Santos (2006), o trabalho de tradução articula o esforço intelectual, o posicionamento político e as disposições emocionais da pesquisadora, desvelando, desde a sociedade, ações empreendidas por pessoas comuns. Penso que este procedimento não pretende "dar a voz" aos excluídos, afinal, não é possível dar a alguém algo que já lhe pertence, mas aliar-me a estas vozes que não se calam, e falar junto com elas. Este ajuntamento com o outro implica na exploração da potência existente, não no sentido de reforçar o que fazem, mas no sentido de usufruir de similaridades, em projetos emancipatórios distintos. Assim, “criar constelações de saberes e de práticas suficientemente fortes [...] para emancipações sociais concretas de grupos sociais concretos num presente cuja injustiça é legitimada com base num maciço desperdício da experiência" (SANTOS, 2006, p. 135).

O relato a ser apresentado, portanto, não é recorte de um corpus de pesquisa mais amplo, mas inscreve-se a partir da relevância outorgada pela autora, a memórias que se entregam a serem trazidas à tona, desde a experiência (LARROSA, 2014) que a acometera. Trata-se do retorno a uma conversação, atividade em fluxo contínuo na vida cotidiana e que 
ainda encontra resistências no âmbito científico, posto que não se sujeita a roteiros previamente estipulados, e nem se ajusta a categorias de análise. Melhor dito por Certeau e colaboradores:

\footnotetext{
É de ser natural e necessária em todo lugar que a conversação provavelmente tira seu estatuto teórico inferior. Como creditar inteligência e complexidade requintada às astúcias de uma prática tão comum? (CERTEAU, M.; GIARD, L.; MAYOL, P., 1996, p. 338).
}

Pois bem. Em visita a uma escola, encontrei um professor e uma turma do ensino médio, envolvidos com uma atividade. Os estudantes tomavam os coloridos selos plásticos que funcionam como lacres de garrafas pet, os cortavam com a tesoura, inseriam um selo através do outro e os colavam novamente, amolecendo as pontas do plástico, no fogo de velas acesas. A atividade resultava em diversas correntes de cores variadas, as quais eram emendadas a outras, e outras. Pelo chão, era possível observar metros de correntes coloridas, e no entorno, envolvidos com o trabalho, os jovens. Aproximei-me do grupo e continuei a observar, mais proximamente. O professor ensinava química na escola, então, brincando, perguntei: o que é isso, gente? Um composto orgânico ou uma cortina para o laboratório? Os estudantes riram e mostraram-me suas "cadeias", e o professor respondeu: a princípio, não é nada.

É claro que o professor não poderia me dizer que aquilo não era "nada", e a coisa terminar ali. Divertido com meu espanto, contou que os estudantes estiveram juntando selos de garrafas, e que aquilo apareceu na sala de aula, e que ele pediu para juntarem mais, muito mais. Selos juntados aos montes, levou-os para o pátio da escola e propôs a atividade; por isso estavam ali, e a única pessoa que estava preocupada com o objetivo daquilo, aparentemente, era eu. Era isso. Não havia um ponto de chegada, embora houvesse planos; não havia um sentido único, mas a certeza de que surgiriam muitos.

Foi o professor quem me disse que, a inexistência de um objetivo, não negava a existência de uma intenção: enquanto eles fazem as correntes, pensam... se eu afirmar o que deve ser, posso prejudicar isso. Não acompanhei os desdobramentos da atividade ocorrida pela manhã naquela escola, mas desconfio de que algo foi produzido ali. No período da tarde, encontrei vestígios do que havia ocorrido, e outros usos que foram oferecidos aos selos.

Uma professora da creche, vizinha à escola, havia trazido seus alunos para os gramados que não existiam naquela, e abundavam nessa. Aproximei-me do grupo e, enquanto conversava com a professora, um dos meninos apareceu carregando algo. Era um pedaço de 
madeira, caído de uma das árvores, o qual ele repousava sobre o ombro, e em cuja extremidade havia uma sacola plástica. Nesta aparição, o menino se assemelhava a um personagem da literatura infantil, fugindo dos perigos, com seus pertences nas costas. Mas... dentro desta sacola - surpresa! - os "restos" da atividade do professor que eu encontrara pela manhã: selos coloridos, agora transformados em outra coisa. O menino brincava, consumindo o que poderia ser tomado enquanto resíduo descartável.

Os mesmos objetos que perpassaram os currículos praticados por uma turma do ensino médio, agora atravessavam a aprendizagem de uma turma de educação infantil. Sem estarem inscritos no currículo prescrito, interferiam junto à produção de conhecimentos e nas relações de ensino e aprendizagem. Classificados como "resíduos sólidos" nas categorias oficiais das coisas existentes, eram tomados como possibilidades para a atribuição de sentidos, quando consumidos de diferentes formas. Receptivos a esse consumo, o professor e a professora incorporavam a novidade ao processo pedagógico, legitimando o inusitado que irrompe em meio ao que é previamente delimitado.

$\mathrm{Na}$ vida cotidiana, os praticantes movem-se anonimamente no lugar do outro, desenhando tramas, cujo destino é o de não serem lidas. Não há um 'leitor' provável para estas tramas, pois nem os caminhantes as revelam em meio à sua própria tessitura, e nem quem se posta em um observatório privilegiado, por elas se interessa. Como diz Certeau (1994, p. 171), "tudo se passa como se uma espécie de cegueira caracterizasse as práticas organizadoras da cidade habitada" - e também as das escolas e de quaisquer outros espaços comuns.

$\mathrm{Na}$ diferenciação que Certeau estabelece entre a apropriação do lugar pelo "forte" e o uso do tempo pelo "fraco", ele faz referência à sucata como a apropriação, por parte do "fraco", de "restos" a partir dos quais ele produz outras coisas. Estes "restos", para Certeau, não se constituem enquanto parte do patrimônio do "forte" furtados pelo "fraco", já que seu valor econômico (ou simbólico) é praticamente inexistente. Nesta prática, Certeau vê outro movimento, a apropriação do tempo: enquanto o lugar é regulado e normatizado pelo "forte", o "fraco" faz uso da ocasião, tecida pelo tempo. Durante o trabalho com sucata, o espaço não é conquistado, mas o tempo é aliado na espera astuciosa pelos "restos", que são furtivamente desviados. A sucata, aqui, se constitui como espécie de metáfora que implica nos produtos criados por praticantes, desde um lugar que lhes é estranho, e com a subversão de uma ordem; 
produtos que não são frutos de uma racionalidade imposta, e que, astuciosamente, desviam a atenção do usufruto de algo bastante precioso: o tempo.

Para pensar sobre o trabalho com sucata, portanto, talvez seja preciso não pensar em sucata, posto que não se deve olhar para ela, mas com ela. O que se passa quando alguém opera intelectual e criativamente, inscrevendo produtos, ideias, desejos e trajetórias que não lhes foram impostos? Bricolagens, inventividade artesanal, pequenas vitórias não capitalizadas, derrisões - diria Certeau (1994). A sucata seria o que o "fraco" obtém junto a este movimento incessante de retomada daquilo de que fora expropriado, e é com ela que ele produz e manifesta os sentidos que delineia. É trabalhando com ela, que ele toma posse, novamente, da inventividade que lhe fora furtada (Idem, Ibidem, p. 88). Note: pensar seus pensamentos, enquanto o "senhor do lugar" desenrola seu rol de normas e instruções, é gerir, novamente, o seu devir. Para Certeau (1994), neste movimento o "fraco" não se compromete com mudanças, posto que sua intenção primeira, se inscreve desde uma cultura imediata. Neste movimento microscópico e invisível, talvez não resida a intenção por organizar uma revolução ou conduzir toda uma suposta legião de "fracos" ao poder; desejoso, tão somente, por gerir seu tempo e expressar sua inventividade, o "fraco" consegue perceber e legitimar, nos que lhe assemelham, o mesmo.

\section{[...] caso não se fique esperando que venha uma revolução transformar as leis da história, como vencer hoje a hierarquização social que organiza o trabalho científico sobre as culturas populares e ali se repete? As ressurgências das práticas "populares" na modernidade industrial e científica mostram os caminhos que poderiam ser assumidos [...] (CERTEAU, 1994, p. 87).}

Exposto às estratégias do "forte", e tecendo astuciosamente suas táticas de escape, o "fraco" ri. Certeau atribui, ao riso, a expressão do conhecimento que o homem ${ }^{12}$ ordinário tem de si, uma manifestação da consciência crítica que ele dispõe sobre o mundo. Diante das esquizofrenias do mundo, ele ri. Certeau encontra este riso em Freud (p. 63), quando o psiquiatra conclui que não é possível falar do homem ordinário, sem deixar de ser um. Aqui, Certeau sinaliza que é inútil tentarmos observar e interpretar o outro, como se nós fôssemos os peritos, pois o que vemos nos outros, somos nós também. Todos somos este "homem ordinário", embora alguns observadores transmutem sua competência de cientistas em autoridade, conforme disse este teórico. Eles se posicionam acima da vida cotidiana e se

\footnotetext{
12 O uso de "homem", neste texto, não será submetido às importantes e necessárias discussões relacionadas ao gênero. $\mathrm{O}$ uso do termo serve, tão somente, à fidelidade ao texto de Certeau, no qual ele trata do "homem ordinário", praticante do cotidiano, também designado como o "fraco" em uma relação.

Momento: diálogos em educação, E-ISSN 2316-3100, v. 26, n. 1, p. 118-142, jan./jun. 2017
} 
esquecem de que são comuns - e ser "comum” é o que mais somos. (Sei que já disse isso, mas como escrever sobre a vida cotidiana, sem repetir?).

Nas cenas descritas, há estudantes, um professor e uma professora que riem, gordos de si. Do lado de fora, eu, a outsider. Certeau (1994) ensina que, há quinhentos anos, em meio à efervescência do nascedouro da modernidade, as pessoas comuns convertiam o desespero imposto pelo caos social, em derrisão. Muitas vezes, impedido de expressar seu desacordo, o "fraco" expressava, em seu riso, o que preservava de si.

\begin{abstract}
O louco zomba. A multidão, aliás, lhe faz eco quando ela tranquiliza o monge: não é nada, é um idiota. Mas o idiota, ele, não pensa em fortalecer o sábio pela abjeção [infâmia] de seu interlocutor. Ele não vem ao socorro da sabedoria, afirmando a nulidade do que ela encontra do outro. Ele é esse próprio "outro". [...] o idiota é um corpo feito para os golpes e os trabalhos baixos, um corpo há muito disseminado, derrisório, que não precisa ser defendido e que não tem mais nada a defender. Sua fraqueza é a força de uma ausência, porque ele já "se tornou lixo". Ele não obedece nem resiste à lei do conflito. Caído no domínio público como a coisa de todos, ele está desligado da propriedade que funda a violência. Ele não fala nem bate. Ele ri. [...] De todos os males só dou risada. Estou livre de medo e de desejo. Esse riso é um não lugar (CERTEAU, 2015, p. 65) (grifo do autor).
\end{abstract}

Há uma escola, há um currículo, há uma avaliação, há um controle. No interior disso, algo se movimenta sorrateiramente, sem dar a perceber que se encontra fora do alcance do poder. Na felicidade gorda de quem fugiu, essa gente ri. No "plano de aula" deve ter sido escrito que, na turma do Ensino Médio matutino, foram ensinados os "polímeros", e no da educação infantil, que foi trabalhado o "pensamento lógico matemático". Mais tarde, quem é de carimbar e assinar tudo isso, carimbou e assinou, e quem estava destinado a ser reduzido a algo que nunca esteve em si, riu. Este riso astucioso, afirmador da diferença e da liberdade, o riso de toda essa gente que vive espremida por entre os limites da regulação, todo esse riso me leva a rir junto com Certeau, quando este riu aos infinitos com Foucault, no momento em que este também ria, dizendo que "não estou, absolutamente, lá onde você está à minha espreita, mas aqui de onde o observo, sorrindo" (apud CERTEAU, 2011, p. 117).

\title{
O PESQUISADOR EM COTIDIANOS, ESSE ESTRANHO
}

$$
\begin{array}{r}
\text { Todos utopistas, inclusive você, } \\
\text { desde que não seja inteira e cegamente submisso, } \\
\text { desde que você deseje outra coisa } \\
\text { e não seja um executante, um esbirro. }{ }^{13}
\end{array}
$$

H. Lefebvre

Ao compartilhar com os (as) afeiçoados (as) a Michel de Certeau a entonação que tecia o seu espírito, seu trabalho, suas relações com seus colaboradores e seus interesses investigativos, Luce Giard, que lhe era tão próxima, conta que ele era uma destas pessoas

${ }^{13}$ Cf. Henri Lefebvre (1991, p. 84).

Momento: diálogos em educação, E-ISSN 2316-3100, v. 26, n. 1, p. 118-142, jan./jun. 2017 
"anticonformistas e perspicazes [...] inconformado com os cânones de uma disciplina rígida, e cuja irradiação intelectual segue caminhos estranhos à lógica das instituições, quer estas se achem ligadas à Universidade, à Igreja ou ao Estado" (CERTEAU, 1994, p. 9). Certeau se desviava desta lógica que arquiteta um método, que funda um dogma, que instaura uma ordem; seu interesse andarilho buscava o que era inventado fora dali, por pessoas comuns, segundo seus modos. Certeau não era um igual, mas sempre um estranho - e ser estranho não o caracterizava, mas o libertava da caracterização, posto que alimentava sua permanente busca e transformação. Interessados em cotidianos, pesquisadores costumam notar em si esta mesma entonação, o que também os leva a mostrarem-se como eternamente estranhos a tudo que não disponha de leveza suficiente para desprender-se da regulação.

O pesquisador em cotidianos é aqui nomeado como "estranho" por não se ajustar aos cânones do pensamento moderno. Segundo o dicionário, o adjetivo "estranho" significa “excêntrico, extraordinário, fora do comum, desconhecido, misterioso, enigmático, espantoso, que foge às normas estabelecidas, que causa um sentimento incômodo e uma sensação incomum". Pois bem, depois deste achado, penso que o pesquisador em cotidianos é um estranho, sim.

Habitando a mesma vida cotidiana que toma como campo de estudos, o pesquisador em cotidianos tem uma dupla tarefa: a de desenvolver seu trabalho, e a de repetir, exaustivamente, os argumentos que comprovem que o que faz é coisa séria. Como afirma Spink (2008), sempre há que se escrever "tratados imensos" quando a opção é pela ruptura com o cânone da cientificidade, pois "não é muito fácil convencer alguém de que sentar em cafés, andar nas ruas, escutar conversas alheias, conversar em filas e olhar a arquitetura urbana é ciência” (p. 75).

O que se privilegia nos estudos em cotidianos, resulta de uma episteme em que o observador não se retira do interior do quadro que observa. Esta opção epistemológica influencia a trajetória investigativa, inserindo diferenciações na relação entre pesquisador e realidade. Vejamos, no quadro abaixo, algumas destas diferenciações entre o que é hegemonicamente observado na vida cotidiana, e as possibilidades de observação perseguidas pelo estudioso do cotidiano: 


\begin{tabular}{|c|c|}
\hline \multicolumn{2}{|c|}{ A vida cotidiana } \\
\hline O que é observado & O que é possível observar \\
\hline Inércia & Movimento \\
\hline Previsibilidade & Imprevisibilidade \\
\hline Certeza & Surpresa \\
\hline Repetição & Novidades \\
\hline Passividade & Criatividade \\
\hline Generalizações & Diferenças microscópicas \\
\hline Anonimato & História não-documentada \\
\hline
\end{tabular}

Quadro 1 - Diferenciações postas à observação da vida cotidiana.

FONTE: arquivo pessoal, 2016

A opção teórica e epistemológica, pela vida cotidiana, inscreve alguns pressupostos importantes que permeiam a prática investigativa de grande parte dos pesquisadores em cotidianos. Um destes pressupostos, é o de que o pesquisador em cotidiano não prescinde da alteridade, e, por isso, acredita no outro. Não se trata, contudo, de uma crença ingênua, mas fundada em um posicionamento crítico e político - algo que esclareço, de forma a não propiciar equívocos. O pesquisador em cotidiano, ao tomar como interlocutor Michel de Certeau (1994), acredita que os sujeitos são praticantes que produzem, inventam, criam, refutam, e usam o que está disposto no mundo. Acreditar na existência destas práticas não implica em uma cega aceitação das manifestações alheias, mas na crença de sua ocorrência e na existência de um "sentido" que as alimente. Devido a isso, pesquisadores em cotidianos não adentram seus campos de estudos com instrumentos e técnicas previamente selecionados, mas se dispõem a encontrar e a perseguir as pistas que o campo lhes oferece (GINZBURG, 1989). A relevância deste trabalho está contida na crença de que os praticantes nos surpreendem, ao compartilhar os sentidos que alimentam suas experiências.

Por interessar-se pelas diferentes lógicas que habitam o que é produzido pelos praticantes, o pesquisador aprende que surpreender-se é uma interessante forma de produzir conhecimentos. Enquanto praticantes anônimos, os consumidores ${ }^{14}$ revelam, em suas narrativas, sinais que diferenciam seus percursos inimitáveis. São praticantes a desenhar trilhas alimentadas por sentidos que privilegiam, causando espanto ao ouvinte que, surpreendido, aprende (LACERDA, 2015a).

14 Em Certeau, sabemos que "consumidores" são as pessoas comuns que habitam a vida cotidiana, e que astuciosamente inventam formas de alterar as bulas prescritivas dos produtos materiais e simbólicos que consomem, através do uso. 
O pesquisador do cotidiano se interessa pela infinitude de micro processos que entrelaçam as vidas das pessoas. Ele persegue os detalhes, sem dicotomizar micro e macro, observando indícios de eventos com escalas e naturezas diversas, presentes no interior de processos microssociais. Por não sucumbir a subordinações ou a determinismos, a percepção do 'grande' no interior do 'pequeno' desvela a dimensão política do cotidiano, presente, também, nas relações entre pessoas comuns. Embora busque analogias com o que se passa no plano global, sua intencionalidade se direciona às práticas anônimas, presentes nos acontecimentos cotidianos, no senso comum, nas narrativas, na memória. Alimentadas pelos incessantes movimentos brownianos ${ }^{15}$, orientadas pelo senso comum, disseminadas pelas narrativas e resguardadas pela memória, no cotidiano habitam diferentes práticas ainda desconhecidas. A legitimidade destas práticas requer o conhecimento de que:

O senso comum é comum não porque seja banal ou mero e exterior conhecimento.
Mas porque é conhecimento compartilhado entre os sujeitos da relação social. Nela
o significado a precede, pois é condição de seu estabelecimento e ocorrência. Sem
significado compartilhado não há interação. Além disso, não há possibilidade de que
os participantes da interação se imponham significados, já que o significado é
reciprocamente experimentado pelos sujeitos. A significação da ação é, de certo
modo, negociada por eles (MARTINS, 2000, p. 60).

Praticantes em cotidianos produzem conhecimentos nomeados como "senso comum", em meio a processos de negociações de sentidos. Tratam-se de conhecimentos legítimos, posto que produzidos na relação social, tecidos pela necessidade e cujos sentidos não são prescritos. Ao pesquisador em cotidiano interessa, sobretudo, o acesso a estes sentidos, a estas negociações e tessituras. Um pesquisador cujo campo lhe serve simultaneamente ao estudo, trabalho e moradia, refuta as fragmentações e ordenações postas ao observar. A impossibilidade da fragmentação do olhar advém do fato de sua observação incidir sobre "lugares praticados", e, portanto, espaços (CERTEAU, 1994). Em Certeau sabemos que o lugar é demarcado e fixo, mas os espaços são tecidos no interior das relações humanas e se estendem indefinidamente, conduzidos por relatos. Cotidianos são espaços que se atravessam, porque não se contêm em si: eles se estendem até qualquer ponto do mundo onde haja alguém tecendo relatos que impliquem no vivido.

Causalidades e determinismos, tão caros à ciência moderna, não provocam o interesse de quem pesquisa em cotidianos, e qualquer linearidade encontrada, é prontamente redesenhada como rizoma. O que lhe interessa, são os diferentes processos tecidos pelos praticantes do cotidiano, seu devir; o resultado de uma ação não lhe chama a atenção, já que

\footnotetext{
${ }^{15}$ Nos estudos em física, "movimentos brownianos" são movimentos aleatórios empreendidos através da colisão de partículas, promovendo organizações caóticas e não lineares. 
entende os cotidianos como histórias sem fins. A recusa à fragmentação, contudo, não se restringe à sua prática investigativa e atividade empírica. Ela também incide sobre suas opções teóricas, cuja natureza epistemológica inventa caminhos metodológicos que acontecem segundo esta episteme. Isso o autoriza a adentrar diferentes campos do saber, sem a intenção de ali se fixar, ou se especializar. Esta é uma herança certeauniana: o estudioso do cotidiano aprende na diferença - aprende, e vai. Como afirma Luce Giard ${ }^{16}$, o estudioso do cotidiano não presta vassalagem a ninguém.

A incerteza sobre o que se passa em cotidiano é acompanhada da certeza de que algo sempre se passa, e isso predispõe o estudo à abertura a eventos caóticos e imprevisíveis. No encontro com o impensado, é também impensável a hierarquização de saberes, culturas e linguagens, o que alimenta o permanente diálogo entre senso comum e ciência, na beleza de uma dupla ruptura epistemológica defendida por Boaventura Santos (2002).

As "artes de fazer" das pessoas comuns impregnam o pesquisador em cotidiano, que com elas aprende a desvencilhar-se de amarras e a autorizar-se, também, a assumir sua autoria. Quanto à minha, a suspendo neste momento para, ao encerrar esta escrita, pedir a Certeau que o faça, despedindo-se por mim com um riso no canto da boca, e uma boa palavra: “ao bom entendedor, um cumprimento" (1994, p. 85).

\section{REFERENCIAS}

AZEVEDO, A. O Cortiço. São Paulo: Martin Claret, 2001.

BAKHTIN, M. (Volochinov) Marxismo e filosofia da linguagem. São Paulo: Hucitec, 1992. BÁRCENA, F. La diferencia (de los idiotas). Pro-Posições, v. 26, N. 1 (76), p. 49-67, jan./abr. 2015.

BARTHES, R. A morte do autor. 2004. Disponível em http://migre.me/tceuM. Acesso em 16/01/2016.

CERTEAU, M. de. A invenção do cotidiano. Artes de fazer. Petrópolis: Vozes, 1994. $\overline{2011 .}$

História e psicanálise: entre ciência e ficção. Belo Horizonte: Autêntica Editora,

A fábula mística. Séculos XVI e XVII. Rio de Janeiro: Forense, 2015.

. et alii. A invenção do cotidiano 2. Morar, cozinhar. Petrópolis: Vozes, 1996.

CHAUI, M. Cultura e democracia. São Paulo: Cortez, 1997.

DEFOE, D. Robinson Crusoe. Audiobook. Disponível em https://librivox.org/robinsoncrusoe-by-daniel-defoe. Acesso em 14/01/2016.

DELEUZE, G. Diferença e repetição. Rio de Janeiro: Graal, 1988.

\footnotetext{
${ }^{16} \mathrm{Na}$ introdução de "A invenção do cotidiano" (CERTEAU, 1994).

Momento: diálogos em educação, E-ISSN 2316-3100, v. 26, n. 1, p. 118-142, jan./jun. 2017
} 
. Conversações. São Paulo: Ed. 34, 1992.

FOUCAULT, M. Vigiar e punir. Petrópolis: Vozes, 1987.

GALLO, S. Deslocamento 3. Rizoma e Educação. In: . Deleuze \& a Educação. Belo Horizonte: Autêntica, 2013.

GINZBURG, C. Mitos, emblemas, sinais: morfologia e história. São Paulo: Companhia das Letras, 1989.

JOYCE, J. Ulysses. São Paulo: Companhia das Letras, 2012.

HELleR, A. O Cotidiano e a História. Rio de Janeiro: Paz e Terra, 1970.

LACERDA, M. P. de. Em práticas pedagógicas e investigativas... a surpresa. Revista Entreideias, Salvador, v. 4, n. 1, p. 7-22, jan./jun. 2015a.

. A vida cotidiana em artefatos da memória. Revista Educação e Linguagens, Campo Mourão, v. 4, n. 7, jul./dez. 2015 b.

LARROSA BONDÍA, J. Tremores: escritos sobre experiência. Belo Horizonte: Autêntica, 2014.

LEFEBVRE, H. A vida cotidiana no mundo moderno. São Paulo: Ática, 1991.

MARTINS, J. de S. A sociabilidade do homem simples. São Paulo: Hucitec, 2000.

Uma sociologia da vida cotidiana. São Paulo: Contexto, 2014.

SANTOS, B. de S. Um discurso sobre as ciências. Porto: Edições Afrontamento, 2002.

A gramática do tempo. Para uma nova cultura política. São Paulo: Cortez, 2006.

SPINK, P. K. O pesquisador conversador no cotidiano. Psicologia \& Sociedade, Porto Alegre, v. 20, n. spe, 2008. Disponível em http://migre.me/tccBa. Acesso em 10 de março de 2016.

TARDE, G. Monadologia e Sociologia. Petrópolis: Vozes, 2003.

VALLA, V. V. A crise de interpretação é nossa: procurando compreender a fala das classes subalternas. Educação \& Realidade, v. 21, n. 2, p. 177-190, jul/dez. 1996. 